MARCIN GIERCZYK

Uniwersytet Ślaski

w Katowicach

\title{
THE CONTRIBUTION OF GIFTED INDIVIDUALS AND NONCONFORMIST BEHAVIOURS TO VIRTUES IN THE PUBLIC SPHERE
}

\begin{abstract}
AвSTRACT. Gierczyk Marcin, The Contribution of Gifted Individuals and Nonconformist Behaviours to Virtues in the Public Sphere [Wkład uzdolnionych jednostek i zachowań niekonformistycznych w cnoty w sferze publicznej]. Studia Edukacyjne nr 47, 2018, Poznań 2018, pp. 197-208. Adam Mickiewicz University Press. ISSN 1233-6688. DOI: 10.14746/se.2018.47.13

Giftedness and nonconformist behaviour have become a source of great interest in both the public sphere and in educational research. This is related to the fact that nonconformity (as a personality and character trait) has been, and still is, an indispensable element of the creative transformation of societies in the public sphere. ${ }^{1}$ The paper presents results of research conducted in the years 2014-2016 on the level of nonconformity of gifted students in Poland and England. The research, conducted with the Creative Behaviour Questionnaire III (CBQ III), was undertaken among 30 purposefully selected students from the University of Silesia (Poland) as well as Oxford University (England). By considering both the influence of nonconformists on the transformations taking place in the public sphere, and also the results of my research, I will examine whether nonconformity is a potential source of strength or weakness to the public sphere. In this context nonconformist is a person who does not conform to a generally accepted pattern of thought or action.
\end{abstract}

Key words: nonconformity, giftedness, virtues, public sphere

\section{Introduction $^{2}$}

Personal interest in research inspired by Ryszarda Bernacka's works on the level of nonconformity of different generations of Poles and earlier Sta-

${ }^{1}$ This is an unpublished conference paper for the 6th Annual Jubilee Centre for Character and Virtues conference at Oriel College, Oxford University, Thursday 4th- Saturday 6th January 2018.

${ }^{2}$ M.P. Pullar, Gifted and overexcitable: positive disintegration, artistic self perception and their impact on adolescent creative writing, Melbourne 2016. 
nislaw Popek's studies prompted me to look closely at the problem and to learn about differences between degrees of nonconformity in students from Poland and England. The literature review of the subject showed no comparative studies in this field, especially in the international context. Knowing the level of nonconformity is essential regarding the impact of nonconformists on the shaping of modern societies and the virtues in the public sphere. The tool to measure levels of nonconformity, i.e. CBQ III survey Ryszarda Bernacka created by modifying the CBQ I questionnaire developed by Stanislaw Popek. ${ }^{3}$ Then, together with Ryszarda Bernacka, we adopted the new questionnaire to the English-speaking conditions.

\section{Gifted Individuals}

The capacity of talented people is an essential resource for every community, and it contributes to the development and advancement of civilisation. Over the centuries, the most significant philosophers have been fascinated by the mystery of human creativity and abilities. Confucius (551-479 BC) believed that gifted children were the wealth of the nation. Socrates (469-399 BC) thought a man should develop in an axiological context, which may, consequently, contribute to the improvement of the functioning of the gifted individuals and their effect on virtues in the public sphere. Plato (428-348 BC) and Aristotle (384-322 BC), also spoke on issues related to the potential of human capacities. Aristotle propounded that everyone is assigned roles according to his ability paradigm. He also emphasised that talent's property is not a constant and we should develop it. ${ }^{4}$ Plato's Ideal State assumed a three-tiered division of society led by philosophers, the wisest, the most honest, and continually perfecting their minds. Plato, in his academy, had a strict selection of pupils, and their primary selection criterion was their outstanding abilities. ${ }^{5}$

The last thirty years of the XXI century is a period of turbulent political and social change in Europe. These changes entailed economic changes, which in turn brought interest to the most talented members of European societies. Research has also been intensified on the education of gifted individuals needed in industry, research institutes, the public sphere and other areas of communities' lives in Europe. However, despite the attainment of outstandingly talented individuals, the approach to them, both at the educational and social level, has been the subject of ambivalence over the years. We may enjoy the products of mental activity of talented individuals, yet we still

\footnotetext{
${ }^{3}$ S. Popek, Kwestionariusz twórczego zachowania KANH, Lublin: 2010.

${ }^{4}$ W. Limont, Uczeń zdolny. Jak go rozpoznać i jak z nim pracować, Gdańsk 2010, p. 40.

${ }^{5}$ T. Giza, Podstawy pracy z uczniem zdolnym, Kielce 2011.
} 
feel the sting of jealousy when we observe how quickly they perform complicated tasks, as well as, their contribution to the virtues in the public sphere. This conflict between public interest and personal feelings is present in many societies and is a significant barrier to the education and functioning of highly gifted students. ${ }^{6}$

\section{Conformist and Nonconformist Behaviours}

Adopting nonconformist behaviour is a common phenomenon, for nonconformity is an element of a creative attitude, ${ }^{7}$ which mostly translates into virtues in the public sphere. Conformity and nonconformity are interdisciplinary concepts. They are the subject of interest in sociology, social psychology, pedagogy as well as creativity. Nonconformity from a sociological perspective is associated with deviant behaviour relating to the public demonstration of opposition to existing norms or values. ${ }^{8}$ While the psychology of creativity talks about conformity (reproductive attitude) and nonconformity (creative attitude). ${ }^{9}$

Nonconformity in the personality psychology is the ability to resist social pressure, the tendency to oppose the opinions, evaluations, views of others, autonomy and independence in the thinking, assessment and action resulting from the autonomous value system. ${ }^{10}$ Stanisław Popek operationalises the dimension of nonconformist personality as thirteen inter-correlative personality characteristics, such as adaptive flexibility, dominance, tolerance, self-organisation, originality, independence, openness, consistency, resilience and persistence, activity, self-criticism, high self-esteem, courage. The intercorrelation of characteristics produces a specific personality energy that triggers, organises, and directs human activity. ${ }^{11}$

This power is the driving force for expressing, executing possibilities and self-updating of a human being. It is particularly active in adolescence, manifesting itself in the behaviour and many other psychological and social aspects of the functioning of the young people. ${ }^{12}$

\footnotetext{
${ }^{6}$ M.P. Pullar, Gifted and overexcitable, p. 84.

7 S. Popek, Kwestionariusz twórczego zachowania.

8 P. Sztompka, Socjologia. Analiza społeczeństwa, Kraków, p. 283.

${ }_{9}$ R.E. Bernacka, E. Misiuda-Kolejko, Uczniowie zdolni nonkonformistyczni i konformistyczni a ich obraz siebie, [in:] Zdolności, talent, twórczość, No. 1, Eds. W. Limont, J. Cieślikowska, J. Dreszer, Torun 2008, p. 163.

${ }^{10}$ R.E. Bernacka, Osobowościowy mechanizm konformizmu i nonkonformizmu - specyfika funkcjonowania i przejawy w zachowaniu, Psychologia Rozwojowa, 2005, 10.

${ }^{11}$ S. Popek, Kwestionariusz twórczego zachowania.

12 R.E. Bernacka, Predyktory nonkonformizmu pozornego, Lublin 2017.
} 
Nonconformity as a personality dimension can thus be presented as a continuum of conformity. Nonconformity makes sense as far as it is visible because its role is to publicly manifest a disagreement over existing rules, to show alternative ways of life. ${ }^{13}$

Nonconformity is also understand as 'a cognitive, emotional and behavioural activity, and becomes the driving force of almost every creative process, provided that apart from negation and opposition to values, the individual produces and expresses in action his ideas and value system. ${ }^{14}$

Positively, nonconformist behaviours do not disrupt the lives of others, although they do not exclude conflicts concerning these responses.

In sociology, the problem of conformity and nonconformity was addressed by Robert K. Merton, who proposed a typology of adaptation to cultural goals, correlated with traditional means to achieve them distinguished: $:^{15}$

1) conformity, which assumes the acceptance of both objectives pursued and means for achieving them,

2) innovation, standing for accepting goals while seeking new solutions,

3) ritualism where there is an absolute compliance of norms with complete abstraction from goals to be fulfilled, retreatism where individual rejects both means, objectives and cultural values,

4) rebellion through which the individual rejects the rules and means, but also proposes new alternatives and values.

Researchers, teachers, parents, educators, and psychologists have been trying for years to understand why people can take on other behaviours that often limit their ability or influence their health or relationships with immediate surroundings.

Over a decade ago, by thinking about why people are conformists, Ryszarda Bernacka distinguished two cognitive positions, namely, the potential and subjectivist vision:

In humanistic psychology, interested in the freedom of self-reflexion and the maximum development of an individual, conformity is the default antithesis of the concept of self-realisation. Subordination, renunciation of individuality, an adaptation of this kind of personalities, which offer cultural patterns, Fromm (1970) calls "escape from freedom." The authentic "self" is suppressed and replaced by "pseudo-self" with dominant pseudo-thought. Man chooses ready-made designs and accepts them as his own, strives to meet the inauthentic needs, which, thanks to defence mechanisms, he

13 P. Sztompka, Socjologia, p. 281.

${ }^{14}$ S. Popek, Zdolności i uzdolnienia w świetle wspótczesnych teorii psychologicznych, [in:] Uczeń o zróżnicowanych zdolnościach i uzdolnieniach we wspótczesnej szkole, Ed. S. Popek, Zamość 2004, p. 74 .

${ }^{15}$ P. Sztompka, Socjologia, p. 281-285. 
perceives as his own, losing his identity. The resignation of spontaneity and individuality and the mercantile orientation of today's people lead to the blocking of the possibility of further development (...). Another aspect considered by humanistic psychologists is the civilisation conditions, and more precisely the changes, the pace and range that have taken place and continue to occur in the modern world. They make all human beings, in fact, unprepared immigrants entering the "new age". ${ }^{16}$

When analysing Bernacka's reflections, we conclude that conformity is an antagonist of creativity and its development. The attributes of 'new age', which the author writes about, are post-industrialism, technological progress, globalisation, modernism, and postmodernism, in shaping which, the role of gifted people is emphasised.

Young people, due to the development of civilisation, ask themselves what is more profitable today - "to face" or "to adapt" to the requirements of the modern world. Bauman stresses that today's recipe for success is "being yourself", "being unlike others," because "the difference, not the identity, sells the best" ${ }^{17}$ Gifted people are often aware of their uniqueness, they are nonconformists and cannot imagine themselves intermingling with the crowd just to fit in. Jan Dzierzgowski notes that there is 'a specific structural constraint of authenticity, creativity and uniqueness, regarded as an inherent element of individualisation. Authenticity, creativity and originality are becoming autotelic values, but these values often make it impossible to build social bonds ${ }^{\prime 18}$ and thus shape virtues in the public sphere.Nonconformity was and is an indispensable part of the creative transformation of society. ${ }^{19}$ Nowadays, young people (born in the 1990s), receive signals from the public about the expected of them "critical potential" which is nonconformity. They are convinced that this is the basis for the development of their creative, cognitive and realisation capacities while at the same time they are aware of three qualitatively different ways of expressing nonconformity. ${ }^{20}$

People need experiments, unusual ideas to stimulate their development, and discover their hidden capabilities ${ }^{21}$ which can be essential for the virtues in the public sphere. Contemporary humanistic descriptions use the term

${ }^{16}$ R.E. Bernacka, Konformizm-nonkonformizm jako wymiar osobowości, [in:] Wierzę w człowieka. Szkice o osobowości, Ed. B. Gawda, Lublin 2001, p. 54-55.

17 Z. Bauman, Kultura w ptynnej nowoczesności, Warszawa 2011, p. 159.

18 J. Dzierzgowski, Przemiany kontroli społecznej a kwestia umiejętności, Socjologia Norm, Dewiacji i Kontroli Społecznej, 2011, 12, p. 50.

${ }_{19}$ R.E. Bernacka i in., Conforming and nonconforming personality and stress coping styles in combat athletes, Journal of Human Kinetics, 2016, 50, 2, p. 225-233.

${ }^{20}$ R.E. Bernacka, Nonkonformizm jako cecha osobowości Polaków trzech pokoleń, Chowanna, 2014, 2, p. 15-234.

${ }^{21}$ B. Dyrda, Edukacyjne wspieranie rozwoju uczniów zdolnych. Studium społeczno-pedagogiczne, Katowice 2012, p. 11. 
so-called modern personality, where independence, innovation, creativity, broad educational aspirations, striving for self-improvement and self-fulfilment are fundamental. ${ }^{22}$

\section{The Level of Nonconformity in the Surveyed Students}

\section{Participants and method}

Taking into account the side effects of education and the influence of psychosocial extra-curricular factors on the functioning of gifted people in the public sphere, which may be a sign of nonconformist behaviour, the diagnosis of the level of nonconformist students from Poland and England seemed interesting to me. Knowing the degree of nonconformity of the investigated people is complementary to the gap in the existing state of theoretical knowledge on the subject. At the same time, a better understanding of the functioning of gifted nonconformists may be relevant in the context of school, education, psychology, and in preventative, didactic and interpersonal aspects. Therefore, I have formulated the following research problem: What level of nonconformity is presented by the investigated gifted students?

\section{Metodology}

In the study, I applied the CBQ III (The Creative Behaviour Questionnaire) (see: appendix 3), modified by Ryszarda E. Bernacka, created by Stanislaw Popek. The revised questionnaire (in Polish) was received personally from the author, and the English version was taken from her publication. ${ }^{23}$ In the CBQ III, Bernacka reduced the number of questions from 60 to 26, and they diagnose 13 features on the scale: conformity - nonconformity and 13 elements on the scale: heuristic and algorithmic behaviour. Reliability of the questionnaire in polish version (scale: heuristic - algorithmic behaviour a $=0.82$, scale: conformity - nonconformity $a=0.80$ ) and English version (scale: conformity - nonconformity $a=0.80$, scale: heuristic - algorithmic behaviour $a=0.83$ ) was satisfactory.

Normality of distribution and homogeneity of variance was tested to answer the question from the research problem. Shapiro-Wilk's Test Z (30) =

22 A. Radziewicz-Winnicki, Pedagogika społeczna, Katowice 2008, p. 280.

${ }^{23}$ R.E. Bernacka, KANH III Questionnaire of Creative Behaviour - presentation of the revised version, [in:] Psychologia twórczości. Nowe horyzonty, [Psychology of creativity. New approaches], Eds. S. Popek, R.E Bernacka, C. Domański, B. Gawda, D. Turska, A. Zawadzka, Lublin 2009, p. 169-175. 
0,95; (irrelevant) normal distribution is satisfactory. Leven's Test $\mathrm{F}(1,28)=$ 0,38 ; (irrelevant) indicates that the difference between variances in the compared groups is statistically insignificant. Therefore, the student's t-test for independent groups was used.

\section{Participants}

The test group in Poland consisted of students from the University of Silesia and the University of Lublin, who were admitted using their Olympiad participant privileges in the academic year 2013/2014 and 2014/2015, while in England I tested Oxford University students from two colleges: Oriel College and Pembroke College.

\section{Findings}

The analysis of a Student t-test (see: Appendix 2) for independent groups has shown that gifted English students differ significantly from capable Polish students on a conformist-nonconformist scale. The level of nonconformity (see: Appendix 1 and Chart 1$)$ in the group of English students $(m=38,4667)$

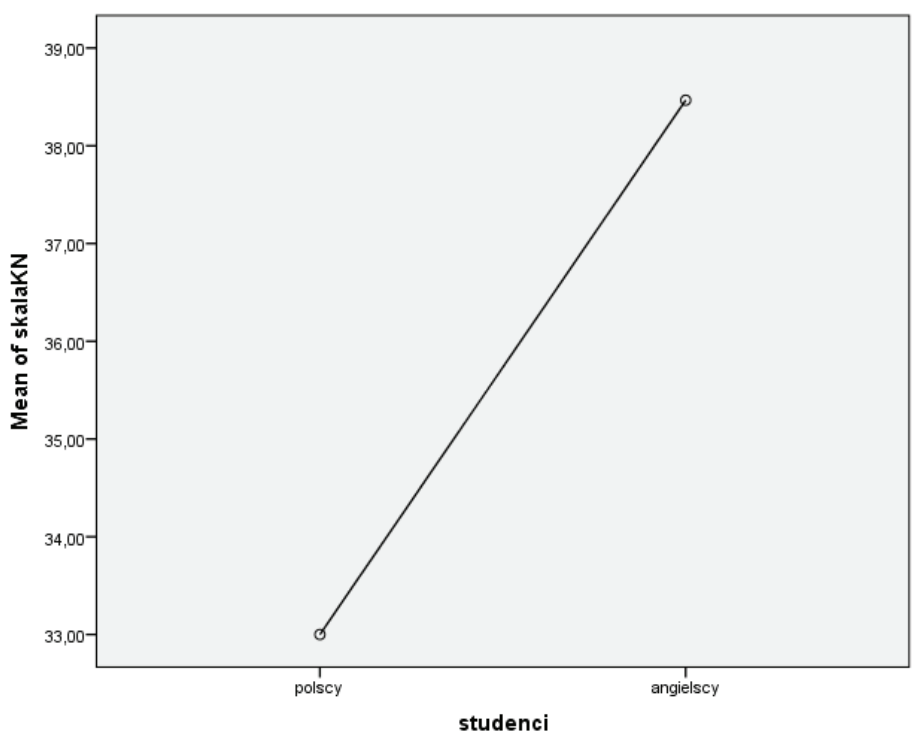

Fig. 1. Nonconformity level in tested groups of Polish and English students 
was significantly higher than in the group of Polish students $(m=33,0000)$. Those differences are predominantly a result of the cultural context, the quality of education in the two different countries, and the teachers' attitude towards nonconformity. In England, nonconformist students are valued, whereas the opposite is true in Poland.

\section{Discussion}

The obtained results, interpreted regarding the cultural context, confirm that the Polish school still favours the development of a conformist attitude, which is mostly influenced by the education system (ie. the way of assessing, transferring knowledge and its reproduction) in which the individual operates. The dominance of conformists among the talented pupils in Poland has already been concluded by Stanislaw Popek ${ }^{24}$ in his studies, and eight years ago by Ryszard Bernacka. ${ }^{25}$ Considering the timing and the transformations that occur in the Polish education system, it shall be noted that persistent advantage of conformists found in my and research mentioned above is undoubtedly disturbing. Also, Asch's study has shown that:

the tendency for conformity in societies is so high, that intelligent and well-intentioned, young people are ready to call white, black. It is a matter of concern about social maladjustment.. It raises the question of the method of education and of the values that govern our behaviour ${ }^{26}$.

In answering the question whether nonconformity is a potential source of strength or weakness to the public sphere, it should be emphasised that nonconformity is, in the light of the Merton's views, an element of the creative processing of the social system, the creation of a 'new order'. ${ }^{27}$

On the other hand, the nonconformist negates values and bypasses norms in the name of first and foremost those who for some reason cannot or do not dare to undertake a constructive change of the applicable cultural or social order. The extreme nonconformity is utopian social current. The form of organisation of social relations based on the strategy of balanced nonconformist

${ }^{24}$ S. Popek, Twórczość, zdolności, wychowanie, Lublin 1989.

${ }^{25}$ R.E. Bernacka, Konformizm i nonkonformizm jako osobowościowy mechanizm asekurujacy osiagnięcia ucznia uzdolnionego, [in:] Uczeń zdolny wyzwaniem dla wspótczesnej edukacji, Eds. J. Łaszczyk, M. Jabłonkowska, Warsaw 2008.

${ }^{26}$ S.E. Asch, Studies of independence and conformity: I. A minority of one against a unanimous majority, Psychological monographs: General and applied, 1956, 70(9).

27 R.K. Merton, Teoria socjologiczna i struktura społeczna, Warszawa 2002. 
behaviour is a democracy. ${ }^{28}$ This research aspect of nonconformity proves particularly interesting for social, cultural, and sociological psychologists. ${ }^{29}$

Adopting the principle of symmetrical reciprocity of conformism in psychological works, we can state that nonconformity as a personality element is a relatively constant tendency of man to opposing opinions, views of other people and ability to resist social pressure. ${ }^{30}$ At the same time, it is a relatively constant autonomy in thinking and functioning in society. It comes down to the fact that an individual evaluates and acts mainly by his position, guided by an autonomous system of values and, if necessary, defends his point of view. ${ }^{31}$

In such approach to nonconformity, one can distinguish two aspects of it. The first - like self-direction - expresses itself in a tendency to autonomy in thinking, evaluating and acting based on an autonomous system of values and the willingness to defend them. The second aspect of nonconformity is the tendency of "social independence" based on or against social pressure and lack of sensitivity to social norms, but without attitude to an extreme violation of them. ${ }^{32}$

\section{Conclusion}

Nonconformist people push the world forward but are not positively judged. Gifted individuals and nonconformist behaviours, in accordance with the views of Robert Merton can be seen as an element of creating "new order" in the public sphere. Its goal is to change well established, routine and currently non-functional ideologies, thought patterns and actions of a group or society. From this point of view, nonconformity and giftedness are a trigger of changes and a development factor of the social system at the level of public sphere.

\section{BIBLIOGRAPHY}

Asch S.E., Studies of independence and conformity: I. A minority of one against a unanimous majority, Psychological monographs: General and applied, 1956, 70(9).

Bauman Z., Consuming life, Malden, MA: Polity Press, Cambridge 2007.

${ }^{28}$ S. Popek, Zdolności i uzdolnienia w świetle wspótczesnych teorii psychologicznych, [in:] Uczeń o zróżnicowanych zdolnościach i uzdolnieniach we wspótczesnej szkole, Ed. S. Popek, Zamość 2004.

${ }^{29}$ S. Popek, W kręgu aktywności twórczej, Lublin 2015.

${ }^{30}$ E.P. Hollander, R.H. Willis, Some current issues in the psychology of conformity and nonconformity, Psychological Bulletin, 1964, 68, 1, p. 62-76.

${ }^{31}$ R.E. Bernacka, Predyktory nonkonformizmu pozornego.

${ }^{32}$ M. Kohn, Class and Conformity. A study in values, Illinois 1969. 
Bauman Z., Kultura w ptynnej nowoczesności, Agora, Warszawa, 2011.

Bernacka R.E., Konformizm-nonkonformizm jako wymiar osobowości, [in:] Wierzę w człowieka. Szkice o osobowości, Ed. B. Gawda, ANNALES, Pedagogika - Psychologia Sectio J, XIV, UMCS, Lublin 2001.

Bernacka R.E., Osobowościowy mechanizm konformizmu i nonkonformizmu - specyfika funkcjonowania i przejawy w zachowaniu, Psychologia Rozwojowa, 2005, 10.

Bernacka R.E., Konformizm i nonkonformizm jako osobowościowy mechanizm asekurujący osiagnięcia ucznia uzdolnionego, [in:] Uczeń zdolny wyzwaniem dla wspótczesnej edukacji, Eds. J. Łaszczyk, M. Jabłonkowska, APS, Warsaw 2008.

Bernacka R.E., KANH III Questionnaire of Creative Behaviour - presentation of the revised version, [in:] Psychologia twórczości. Nowe horyzonty, [Psychology of creativity. New approaches], Eds. S. Popek, R.E Bernacka, C. Domański, B. Gawda, D. Turska, A. Zawadzka, UMCS, Lublin 2009.

Bernacka R.E., Nonkonformizm jako cecha osobowości Polaków trzech pokolen, Chowanna, 2014.

Bernacka E.R., Predyktory nonkonformizmu pozornego, UMCS, Lublin 2017.

Bernacka R.E., Misiuda-Kolejko E., Uczniowie zdolni nonkonformistyczni i konformistyczni a ich obraz siebie, [in:] Zdolności, talent, twórczość, No. 1, Eds. W. Limont, J. Cieślikowska, J. Dreszer, WUMK, Toruń 2008.

Bernacka E.R., Sawicki B., Mazurek-Kusiak A.K., Hawlena J., Conforming and nonconforming personality and stress coping styles in combat athletes, Journal of Human Kinetics, 2016, $50,2$.

Dyrda B., Edukacyjne wspieranie rozwoju uczniów zdolnych. Studium społeczno-pedagogiczne, Wydawnictwo Akademickie Żak, Katowice 2012.

Dzierzgowski J., Przemiany kontroli społecznej a kwestia umiejętności, Socjologia Norm, Dewiacji i Kontroli Społecznej, 2011, 12.

Gallagher J.J., Current and Historical Thinking on Education for Gifted and Talented Students, ERIC, Washington 1994.

Giza T., Podstawy pracy z uczniem zdolnym, Wszechnica Świętokrzyska, Kielce 2011.

Hollander E.P., Willis R.H., Some current issues in the psychology of conformity and nonconformity, Psychological Bulletin, 1964, 68.

Kohn M., Class and Conformity. A study in values, Dorsey Press, Illinois 1969.

Limont W., Uczeń zdolny. Jak go rozpoznać i jak z nim pracować, GWP, Gdańsk 2010.

Merton R.K., Teoria socjologiczna i struktura społeczna, Wydawnictwo Naukowe PWN, Warszawa 2002.

Pullar M.P., Gifted and overexcitable: positive disintegration, artistic self-perception and their impact on adolescent creative writing, Melbourne Graduate School of Education, Melbourne 2016.

Popek S., Twórczość, zdolności, wychowanie, UMCS, Lublin 1989.

Popek S., Zdolności i uzdolnienia w świetle wspótczesnych teorii psychologicznych, [in:] Uczeń o zróżnicowanych zdolnościach i uzdolnieniach we wspótczesnej szkole, Ed. S. Popek, WSH-E, Zamość 2004.

Popek S., Kwestionariusz twórczego zachowania KANH, UMCS, Lublin 2010.

Popek S., W kręgu aktywności twórczej, UMCS, Lublin 2015.

Radziewicz-Winnicki A., Pedagogika społeczna, AiP, Katowice 2008.

Sztompka P., Socjologia. Analiza społeczeństwa, Wydawnictwo Znak, Kraków 2007. 


\section{APPENDIX}

Appendix 1. Descriptive statistics

\begin{tabular}{|l|l|l|l|c|c|}
\hline & Students & $\mathrm{N}$ & Average & $\begin{array}{c}\text { Standard } \\
\text { deviatione }\end{array}$ & $\begin{array}{c}\text { Standard error } \\
\text { of the meanj }\end{array}$ \\
\hline \multirow{2}{*}{$\begin{array}{l}\text { Scale } \\
\text { KN }\end{array}$} & Polish & 15 & 33,0000 & 5,63154 & 1,45406 \\
\cline { 2 - 6 } & English & 15 & 38,4667 & 4,71876 & 1,21838 \\
\hline
\end{tabular}

Appendix 2. T-student's test for a group of Polish and English gifted students

\begin{tabular}{|l|c|c|c|c|c|c|c|}
\hline & \multirow{2}{*}{$\begin{array}{l}\text { Scale } \\
\mathrm{KN}\end{array}$} & $\mathrm{t}$ & $\mathrm{df}$ & $\begin{array}{c}\text { Two- } \\
\text {-tailed } \\
\text { signifi- } \\
\text { cance }\end{array}$ & $\begin{array}{c}\text { Mean } \\
\text { diffe- } \\
\text { rence }\end{array}$ & $\begin{array}{c}\text { Stand- } \\
\text { ard } \\
\text { error } \\
\text { of the } \\
\text { differ- } \\
\text { ence }\end{array}$ & $\begin{array}{c}\text { 95\% confidence inter- } \\
\text { val for the difference } \\
\text { between means }\end{array}$ \\
\cline { 2 - 8 } & $-2,8882$ & 28 &, 008 & $-5,46667$ & 1,89703 & $\begin{array}{c}\text { Inferior } \\
\text { limit }\end{array}$ & $\begin{array}{c}\text { Supe- } \\
\text { rior } \\
\text { limit }\end{array}$ \\
\hline
\end{tabular}

Appendix 3. CBQ III

The questionnaire CBQ III (The Creative Behaviour Questionnaire) contains statements concerning different human activities and processes that take place while learning or while performing an action. In order to answer the questions, please underline the letter corresponding to the answer which you agree with most. Do not omit to mark any statements.

No

STATEMENT

1 I enjoy expressing my thoughts in writing.

2 I quickly adapt to new places and situations.

3 I inquisitively analyse any new information or phenomenon I come across.

4 I enjoy being in charge of people and situations.

5 I believe other people are entitled to their own opinions, views and beliefs, even if I do not agree with them.

6 I solve problems independently, without following other people's ideas.
A - yes

B - probably yes

C - no opinion

D - probably no

E - no

A B C D E

A B C D E

A B C D E

A B C D E

A B C D E

A B C D E 
7 I deal with new or difficult situations most efficiently when A B C D E I can work independently.

8 When I study, I always aim to understand the crux of the

A B C D E issue

9 I attach great importance to performing tasks in a way that is different to how other people of my age group perform them.

10 I am artistically gifted/talented.

A B C D E

11 I enjoy daydreaming and I have plenty of original ideas.

A B C D E

12 I usually make decisions independently and am not influA B C D E enced by pressure from other people.

13 I am curious about everything that surrounds me.

A B C D E

14 I try to approach a given task from various angles.

A B C D E

15 I like it when somebody gives me hints on how to learn..

A B C D E

16 I support all innovations.

A B C D E

17 I construct and improve the appliances I use in my own en-

A B C D E vironment.

18 I reach my goals despite any difficulties.

A B C D E

19 New and convincing arguments usually make me change

A B C D E my point of view.

20 I perform strenuous and difficult tasks with persistence and

A B C D E enthusiasm, right up to the end.

21 I like to expand my knowledge and I don't need encouragement to do that.

22 I enjoy taking the initiative and acting accordingly.

A B C D E

23 I like thinking of various improvements in my environment.

A B C D E

24 I am cautious when expressing an opinion for the fear of

A B C D E being ridiculed?

25 Before I comply with regulations or directives, I first check

A B C D E if they make sense.

26 I feel that I am better than others and this encourages me to act.

A B C D E

Please provide your age Your gender Thank You 